\title{
Exchange Rate Trends and Management in India ${ }^{1}$
}

May 31, 2015

\author{
Michael M. Hutchison \\ Department of Economics \\ University of California, Santa Cruz \\ Santa Cruz, CA 95064 \\ hutch@ucsc.edu
}

Gurnain Pasricha
International Economic
Analysis Department
Bank of Canada
Ottawa, Canada
gpasricha@bankofcanada.ca

\footnotetext{
${ }^{1}$ We would like to thank Bryce Shelton for excellent research assistance. The views expressed in this paper are those of the authors. No responsibility for them should be attributed to the Bank of Canada.
} 


\section{Introduction}

This chapter evaluates developments in India's nominal and real exchange rates over the past two decades, describing longer-term trends as well as short-term movements and volatility. Exchange rate movements are influenced by a host of factors including government policy, especially foreign exchange market intervention, capital controls and monetary policy. We explore how different dimensions of these policies in India have influenced the exchange rate. Explaining short-run exchange rate movements statistically by a stable set of macroeconomic variables is an elusive task which is not settled in the literature. Given the state of the academic and policy literature on short-term exchange rate determination, our empirical focus is on longterm trends and volatility in the nominal and real Rupee exchange rates, and a broad exploration of the explanatory roles of the main policy determinants--foreign exchange market intervention, opening of the capital account, and monetary policy.

India's exchange rate management and monetary policy are closely linked as the Reserve Bank of India (RBI) is responsible for foreign exchange market interventions and is the manager of the foreign exchange regulation act (FEMA, 2004), with the mandate of "promoting the orderly development and maintenance of foreign exchange markets in India”. ${ }^{2}$ Maintenance of foreign exchange markets is associated with very active management of controls on international capital movements and frequent foreign exchange market intervention operations in addition to consideration of the effects of interest rate changes on the exchange rate. These considerations make understanding the linkages between monetary policy, capital controls and foreign exchange market intervention operations central to a study of exchange rates in India. ${ }^{3}$

We begin in section 2 with a statistical representation and analysis of various Rupee exchange rate measures, nominal and real as well as bilateral and trade-weighted multilateral, and demonstrate that evaluation of short-term movements and longer-term trends depend critically on the particular measure of interest. We identify three "regimes" during which the exchange rate trends and volatility exhibited quite distinct patterns. Long-term trends are very interesting, pointing longer-term depreciation of the Rupee (broad-based multilateral) largely offsetting the relatively high inflation in India, with small changes in the longer-term real value of the currency, i.e. long-term PPP holds for a broad multilateral measure of the nominal exchange rate,

\footnotetext{
${ }^{2}$ Quotation from RBI website: https://www.rbi.org.in/scripts/FS Overview.aspx?fn=5

${ }^{3}$ The flipside is that the exchange rate enters into the RBI's policymaking not only due to its impact on inflation but also its potential impact on economic growth directly and on financial stability. In countries where central bank targets inflation (since 2015 for the RBI) and the central bank credibility is high, exchange rate pass-through to inflation is typically low. Many advanced economies have seen the exchange rate pass through decline over time (BIS, 2005), and central banks worry about exchange rate movements mainly to the extent that they affect current or expected inflation.
} 
By contrast, the bilateral USD/INR exchange rate shows a high degree of short- and long-run movement that is not offsetting inflation rate differentials between India and the U.S. Section three considers the policy levers that affect exchange rates-- exchange rate management-- and in particular whether foreign exchange market intervention and changes in the intensity of capital controls are consistent with, and directed toward, an exchange rate objective. This section also considers how intervention and capital controls interact with monetary policy in navigating a balance between external and internal policy objectives. Section four concludes.

\section{Nominal and Real Exchange Rates: Bilateral and Trade-Weighted Baskets}

\subsection{Trends, Patterns and Volatility}

India has been developing its foreign exchange market and the average daily turnover in the onshore market spot + forward) increased from 2.7 billion USD in March 1999 to about 30 billion USD in March 2015. ${ }^{4}$ Figure 1 shows the development of three nominal exchange rate measures for the Indian Rupee (INR) from 1993 through the beginning of 2015: the U.S. Dollar/INR exchange rate, the nominal INR against a basket of six major currencies partners, and the nominal INR against a basket of 36 trading partners. ${ }^{5}$ The base for each index is set at 100 for January 1998, and a decline in the index represents a fall in the value of the Rupee. Monthly data is shown. Figure 2 shows the month-to-month percentage change in the three INR indices.

Four distinctive trends in the INR rate are identifiable in Figure 1, consistent across the three INR measures and denoted by vertical lines: (a) a period of gradual and fairly steady depreciation of the INR, from 1993-2002; (b) a period of moderate fluctuations but no trend movement in the exchange rate (2002-07); (c) a period of sharp depreciation and very high volatility from 2008-13; (d) a period of some appreciation and greater stability. The 1998-2015 cumulative depreciation in the USD/INR rate was about $40 \%$, while declining on a broad (narrow) trade-weighted basis by almost 30\% (45\%).

It is evident from Figure 2 that high volatility and turbulence in the INR during 2008-13 is quite distinct compared with the relative stability of the three other periods. Generally, month-tomonth fluctuations in the INR/USD rate over most of the sample have been within a $+/-2.5 \%$ band, shown in the figure. The exchange rate volatility of the Global Financial Crisis and its aftermath is distinct from the other periods in the sample, characterized by the frequency of days exceeding the $2.5 \%+/$ - band.

Depreciation of the nominal INR against the USD and multilaterally is a dominant trend over several decades. However, measures of the real exchange rate reveal quite different patterns.

\footnotetext{
${ }^{4}$ Source: Reserve Bank of India, Database on the India economy. The numbers cited are the sum of merchant and interbank purchases and monthly averages of daily data.

${ }^{5}$ See appendix A for data sources and descriptions.
} 
Figure 3 shows the corresponding real exchange rates for the three nominal indices previously discussed. The three measures are the real USD/INR exchange rate, the six-country tradeweighted real multilateral exchange rate, and the 36-country trade-weighted real multilateral exchange rate. The base is set to 100 in January 2001. A rise in each index implies a real exchange rate appreciation. We again distinguish four exchange rate episodes by vertical lines.

The indices demonstrate substantial cumulative real exchange rate appreciation over more than two decades against the U.S. Dollar (more than 40\%) and, to a lesser extent, a narrow basket (six countries) of leading currencies (more than 20\%). But against a broad basket of 36 currencies the INR has appreciated relatively little (8\%) and was at virtually the same real value in the beginning of 2014 as early 1993. Only strong real appreciation in 2014 pushed the real value of the 36-country weighted exchange rate above its stable "Purchasing Power Parity" (PPP) value.

Different patterns again emerge during our sub-samples. (a) The first period, 1993-2002, shows a relatively steady real exchange rate by all three measures, with fluctuations above and below the base level. (b) Trend appreciation across the three measures, but mainly against the USD, is evident during the second period, 2002-07. (This contrasts markedly with the relatively steady nominal exchange rate values during this period). (c) The third period, 2008-13, again shows substantial instability and volatility with alternating bouts of real depreciation followed by rebounds. Movements in the real USD/INR rate were greatest, with a real value index of 138 in December 2007, falling to a low of 115 in February 2009 and then sharply appreciating to 162 by July 2011. Substantial depreciation again followed, reaching 128 by August 2013. The other measures followed a similar pattern, but with less extreme movements, ending this episode (August 2013) with the narrow (6 country) index at around the same level as the start and about a 10 percent cumulative real depreciation against the broad (36 country) multilateral index. (d) The final episode in our sample, August 2013 through January 2015, showed substantial real appreciation across the three indices - much greater rates of appreciation than evident for the nominal indices during the most recent sub-sample period.

In terms of real exchange volatility, shown in Figure 4, all three indices show substantial fluctuations over the sample period, frequently exceeding the $+/-2.5 \%$ band. This is substantially more volatility than seen for nominal exchange rates. Again volatility was greatest for real, as well as nominal, exchange rate volatility during the GFC and its aftermath (2008-13).

The divergent trends in nominal and real exchange rates are explained, by definition, by relative price developments in India and its counterparts in the currency baskets. This is shown is Figure 5 for the two cases with the greatest and least divergences between real and nominal exchange rates, respectively, the USD/INR rate and the 36-country multi-lateral exchange rate. The figure shows two series-- the relative Indian price level against the U.S. and the relative Indian price level against a trade-weighted average of 36 countries. Figure 5 shows that, since 2001, the relative Indian price level climbed more than 90 percent compared to the U.S. price level and almost 50 percent against a broad price index of trading partners. The comparatively rapid rise in 
the Indian price level explains why the USD/INR exchange rate appreciated by 42 percent in real terms over this period despite an almost 30 percent depreciation in the nominal exchange rate. By contrast, the modest 11 percent appreciation of the INR against the broad currency basket during 2001-15 period reflects the effect of a 25 percent nominal deprecation largely offsetting the much greater rise in the Indian price level relative to its trading partners.

\subsection{Long-term Linkages Between Prices and Exchange Rates: PPP}

The descriptive analysis indicates the Indian real exchange rate against the USD has shown a much larger trend appreciation, and greater volatility, than against a broad basket of currencies. These observations are borne out by formal co-integration tests where we test whether purchasing power parity (PPP) holds in the longer-term. This procedure amounts to testing for a long-term linkage (co-integration) between the (log) nominal exchange rate and (log) relative prices. Formal PPP would indicate a 1:1 long-term (negative) linkage between the nominal exchange rate and prices. However, we postulate a weaker relationship, testing whether a cointegrating vector exist between the nominal exchange rate and relative price, allowing for a constant and linear trend as deterministic variables. We consider both the Granger-Engle and the Phillips-Ouliaris (residual) tests of co-integration and report both the tau-statistic and the zstatistic. The null is that the nominal exchange rate and relative prices are not co-integrated, hence rejecting the null indicates a long-run relationship between the two series.

Table 1 reports the results of the co-integration tests for the USD/INR exchange rate and the Indian/US relative CPI price. Table 2 reports the results between the broad multilateral exchange rate index and the Indian-foreign country weighted relative price index. The first part of each table reports the point estimates of the long-run relationship (using fully modified least squares), including a constant term and linear trend, and the second part reports the formal co-integration tests on the residual series.

Comparing the point estimates across the two series, it is evident that the linkage of relative Indian price level bilaterally against the USD is much weaker than against the multilateral basket of currencies, i.e. the point estimate of the former is -0.42 (USDINR rate depreciates only $0.42 \%$ in response to a 1\% rise in relative price level in India relative to U.S.) and the point estimate of the latter is -0.82 (trade-weighted nominal exchange rate depreciates $0.82 \%$ in response to a $1 \%$ rise in relative price level in India relative to group of trading partners). The PPP restriction of 1.0 as a co-integrating term is decisively rejected for both equations at the 1 percent level of significance. In line with observations of volatility, the long-run variance estimate against the USD is much larger than against the basket of currencies.

Not surprisingly, co-integration is strongly rejected between exchange rates and prices in India and the U.S. by both the Granger-Engle and Phillps-Ouliaris tests (Table 1). Trend movements in the USD/INR exchange rate simply do not reflect longer-term movements in relative prices between the two countries. 
Co-integration is not rejected, however, between relative prices and the multi-lateral exchange rate (Table 2). Three of the test statistics reject the "no co-integration" null at the 5 percent level of significance, and the fourth rejects at the 6 percent level. This is strong descriptive and statistical evidence that longer-term trends in the Indian nominal exchange rate, measured as a weighted average of a large group of trading partners, reflects relative movements in price levels. It appears that a weak form of PPP holds, meaning that the real exchange rate for a broad basket of currencies shows large fluctuations over the short- and medium-term horizons but reverts to a stable trend over longer-periods - the nominal exchange rate largely adjusts to offset relative price movements over longer periods.

\section{Exchange Rate Policy: intervention, capital controls and monetary policy}

Although long-term movements in the INR exchange rate may largely reflect relative price trends between India and its trading partners, as well as real factors such as relative productivity developments and other "real" shocks, short-and medium-term fluctuations are influenced by a host of factors including government policy, especially foreign exchange market intervention, capital controls and monetary policy. The objectives of an exchange policy are typically multifaceted, but generally focus on mitigating exchange rate volatility and turbulence as well as influencing the medium-term path of the exchange rate. However, the mix of policies is also constrained by the "trilemma" which suggests limits to independent policies across three dimensions: exchange rates, external capital controls (financial openness) and monetary policy. We explore how different dimensions of policy in India may have influenced the exchange rate. In what follows, we discuss intervention, capital controls and monetary policy as they relate to capital inflows and exchange rates.

\subsection{Exchange Rate Policy and Intervention}

Mitigating exchange rate volatility has been an explicit objective of the Reserve Bank of India (RBI) for decades, long acknowledged in official documents and speeches. RBI is also the manager of the Foreign Exchange Management Act (FEMA) 1999, which gives it powers to regulate the foreign exchange markets in India. Moreover, the RBI used capital controls as well as foreign exchange intervention to stabilize the exchange rate or to lean against the wind, to give some room to monetary policy responsive to domestic conditions. However, the constraints of the trilemma seemed to bind for most of the sample period, particularly after the 2008 global financial crisis, limiting monetary policy autonomy.

The tension between maintaining exchange rate parities and allowing flexibility is evident throughout our sample period. The first episode (1993-2002), discussed in the previous section, was one of relative stability in exchange rates and marked by gradual trend depreciation. Since that time considerably more exchange rate variations is evident, caused partly by the nature of 
the domestic and external environment and partly by gradually opening of the external financial flows and willingness of the authorities to allow greater exchange rate flexibility as a "shock absorber” to external shocks. Greater financial openness and flexibility in exchange rates has also been encouraged by the IMF. For example, the 2013 IMF Article IV Consultation Report lauds the virtues of exchange rate flexibility and states that: "The floating Rupee is an important shock absorber. Rupee flexibility has offset inflation differentials and prevented exchange rate misalignment. Such flexibility would be particularly important in case of renewed global financial stresses.” (IMF, 2013, p. 20) ${ }^{6}$. Policymakers allowing greater flexibility in recent years is consistent with the evidence in the section 2 on how exchange rate depreciation is offsetting high inflation rates in India compared with its trading partners, Similarly, even in the face of quite high exchange rate volatility following the GFC and its aftermath, the 2015 report states: “Given India's increased and adequate reserve buffers, greater exchange rate flexibility would be welcome and thereby encourage private sector entities to limit excessive risk taking. Foreign exchange intervention should be limited to preventing disruptive movements in the exchange rate. If global financial market volatility resurfaces, exchange rate flexibility should be an important shock absorber.” (IMF, 2015, p. 21).

Although the India authorities may accept greater exchange rate flexibility, the authorities have nonetheless continued to engage in extensive interventions in the foreign exchange market Figure 7 shows the accumulation of foreign exchange reserves in India from the RBI database and measured in (monthly) flows in billions of USD. This is a measure of foreign exchange intervention, with increases representing purchases of USD in the foreign exchange market and decreases representing sales of USD in the foreign exchange market. Generally, purchases of dollars (sales of INR) by the RBI in the foreign exchange market are designed to limit INR appreciation and are one measure of how the RBI is attempting to influence the exchange rate through intervention operations. Sales of dollars (purchases of INR) are designed to limit INR depreciation.

There is a sharp asymmetry in the use of official reserves policy to manage nominal exchange rate. During periods of nominal exchange rate appreciation pressures, particularly from January 2002 to May 2008, reserves accumulation was actively used to lean against the wind. India's international reserves (excluding gold) climbed more than six-fold during this period, from 47 billion USD to 305 billion USD. However, during periods of depreciation, there was a reluctance to sell off reserves. The total intervention (spot and forward) during the global financial crisis period of June 2008 to May 2009, amounted to only 19 percent of India's total foreign exchange reserves (excluding gold) of 305 billion USD-- spot sales of the USD during June 2008 to May 2009 totalled 43 billion USD_ and the exchange rate depreciated significantly. Similarly, the level of USD purchases during the tapering episode of May to September 2013 did not match the

\footnotetext{
${ }^{6}$ The reports are not always consistent in the views expressed about the merits of exchange rate flexibility, however.
} 
rate of reserves accumulation in the pre-2008 period or the rate of accumulation during 2014 when Rupee appreciation pressure re-emerged. Overall, the RBI accumulated reserves rapidly during periods of exchange rate appreciation pressures, but resisted using reserves to limited nominal depreciations. This strategy reflected a "fear of losing reserves" as India is largely a current account deficit country, and has been outlined in RBI documents. ${ }^{7}$

It appears that much of foreign exchange purchase operations, involving large scale sales of the Rupee, were sterilized so as not to allow an expansion of the monetary base. For example, when the RBI ran out of government bills/bonds to sell to sterilize foreign exchange reserves purchases, on 23 February 2004, it announced the launch of a market stabilization scheme to issue additional government bills/bonds explicitly as sterilization instruments. ${ }^{8}$ At the peak, reserve purchases (both spot and forward) were about 22 billion USD a month in 2007. However, during the 2008 global financial crisis, foreign exchange reserves were not used to stabilize a depreciating exchange rate, with sales being negligible. During 2009, the reserves accumulation resumed in periods of appreciation pressures, but compared to the pre-2008 period, the extent of accumulation remained subdued, picking up again in 2014.

In summary, intervention policy in India has been directed toward limiting exchange rate appreciation, during which times dollar purchases were generally large, and not directed toward limiting depreciation. The general trend in exchange rate depreciation in nominal terms over our sample period was facilitated by intervention policy. This policy may have allowed relative stability in the real exchange rate, hence maintaining India export competitiveness, as the exchange rate depreciated over longer-periods to offset relative high inflation in India. Intervention policy and exchange rate depreciation also allowed greater monetary autonomy, especially during a period associated with increased financial liberalization of the international capital account. Moreover, reserve accumulation - through USD purchases on the foreign exchange market - is a desirable objective to the extent that it provides a stock of precautionary reserves in the event of a balance of payments/currency crisis or sudden stop in private capital inflows that generally finance persistent current account deficits in India. On the other hand, the exchange rate did not play the role of a "nominal anchor" of monetary policy and high inflation in India as a consequence has been a recurring problem.

\subsection{Capital Controls and Exchange Rates}

Control of international financial capital movements is another policy instrument that is employed to influence financial flows in and out of India and the exchange rate. Although an overall trend towards financial liberalization of the capital account, i.e. lifting of restrictions on

\footnotetext{
${ }^{7}$ See Reserve Bank of India (2013), Intervention in the Foreign Exchange Markets: the approach of the reserve bank of India", remarks prepared for Emerging Markets Deputy Governors' Meeting, hosted by the BIS. Available at: http://www.bis.org/publ/bppdf/bispap73l.pdf

${ }^{8}$ See RBI announcement at : https://www.rbi.org.in/scripts/BS_PressReleaseDisplay.aspx?prid=9788
} 
capital flows, capital controls have been used actively as an instrument to "lean against the wind" of exchange rate pressures.

A measure of cumulative changes in the capital account is shown in Figure 8. These data are from Pasricha, Falagiarda, Bijsterbosch and Aizenman (2015). Each of the capital account openness indices is the cumulative sum of the number of weighted capital control easings less tightenings per quarter. The changes are weighted by the share of the country's international balance sheet the measures are designed to impact (The weights are from Lane and MilesiFerretti). Four indices are shown: cumulative changes for easings less tightenings for total capital inflows (outflows) and the total less FDI.

Net easing of capital inflows (both with and without FDI included) is a gradual and persistent trend throughout 2001-11, with various degrees of intensity. However, net easing of restrictions on capital outflows is more sporadic and occurred mainly in two episodes, 2003-04 and 200608. ${ }^{9}$ While the capital controls index is only available through the end of 2011, the period 2012 to 2014 was characterized by net capital inflow increasing measures. There was substantial easing of inflow controls, particularly on foreign borrowing by residents, as well as some tightening of outflow controls, particularly during the taper tantrum period.

Substantial capital control changes appear associated with the major changes in nominal exchange rate trends in India identified in the previous section.

o There are only two periods during which the liberalization trend was temporarily reversed through a net tightening of inflow controls - 2003-4 and 2006-08. Both these were periods of periods of appreciating nominal INR/USD exchange rate. These periods also saw several net liberalizations of outflow controls, as authorities attempted to reduce exchange rate appreciation pressure associated with surging net capital inflows.

o There was significant net liberalization of inflow controls after 2008, particularly during 2008, 2011 and 2013, the years that saw sharp depreciations of the Rupee. The year 2013 also saw tightening of outflow controls in response to the net capital outflow pressures.

Changes in capital inflow controls in India responded systematically to exchange rate pressures, presumably in an attempt to moderate exchange rate movements. This issue is addressed directly using an event study methodology by Pandey et al (2015). A figure from their work is shown as

\footnotetext{
${ }^{9}$ The de-jure liberalization resulted in de-facto liberalization, as measured by deviations from covered interest parity. Hutchison, Pasricha and Singh (2012) use a self-Exciting Threshold Auto-Regressive (SETAR) model to the interest differentials between the onshore interbank rate and offshore-NDF implied (covered) yield over the period 1998-2011 and find that prior to 2008, capital control tightenings were able to create a wedge between the offshore and onshore interest rates, but only in periods in which the controls were actively tightened (March 2003August 2005 and August 2006- October 2008). They also find that post-2008, the no-arbitrage band for the differentials fell to close to zero.
} 
Figure 9. This study finds that the 68 episodes of net capital inflow easing is associated with periods of INR exchange rate depreciation (rising INR/USD four weeks prior to changes in controls) and the 8 episodes of net capital inflow tightening is associated with periods of INR appreciation (fall INR/USD ten weeks prior to changes in controls).

However, while capital controls on both inflows and outflows were used to respond to nominal exchange rate pressures, it is not clear that these measures delivered on reversing the exchange rate trend or even stabilizing it. Pandey et. al. (2015) also address this issue. They employ a propensity score matching methodology to assess the causal impact of changes in a certain type of inflow controls (those on foreign borrowing by Indian residents) for the period from January 2004 to September 2013. The propensity score matching methodology controls addresses selection bias that would arise in a simple event study or regression if policymakers use capital controls for exchange rate management purposes. The weeks in which capital control actions (CCAs) were implemented will differ in identifiable ways, from weeks in which CCAs were not implemented. The propensity score matching (PSM) methodology is a way of building the counterfactual of what would have happened if the controls had not been employed. Instead of trying to model the outcome variables, the methodology shifts focus to modelling the policy variable (the use of a CCA) and estimating the conditional probabilities for the use of CCAs. These conditional probabilities, called propensity scores, are used to identify time periods that had similar characteristics to those prior to the date of the CCA but where no CCA was employed (control group). The behaviour of the outcome variables for the control group gives a counterfactual for how each of these variables would have behaved had the CCA not been employed. Outcomes the weeks after the CCA are compared between the treatment and control groups.

Figure 10 which is an updated version of the one in Pandey et al. (2015) plots the difference between nominal INR-USD spot exchange rate between treatment and control weeks for easing of capital controls on foreign borrowing. It shows no significant difference between the outcomes after easing CCAs and the outcomes in control periods. This result also held for other outcome variables. On balance, they find that these controls did not significantly impact either nominal or real exchange rate movements.

Pandey et. al. consider a longer sample, but one interesting episode is the period of "taper tantrum”, May - September 2013. The taper tantrum began after Bernanke’s testimony to the US congress on 22 May 2013 that the Federal Reserve "could take a step down in our pace of purchase” of assets under the QE program, conditional on improving economic conditions ${ }^{10}$. These events led to considerable market volatility and a global retrenchment from risk taking, with market participants interpreting the statements to suggest that the Federal Reserve may start normalizing policy earlier than markets had so far expected.

\footnotetext{
${ }^{10}$ The FOMC press conference in June further reiterated that the asset purchases could slow in the fall of 2013, conditional on the economic recovery continuing to take hold.
} 
This retrenchment from risk-taking hit India particularly hard, as at that time the economic fundamentals appeared to be weak, with slowing growth, high inflation, high fiscal deficit and political uncertainty due to the upcoming 2014 general elections. The Indian policy response consisted of tightening of monetary policy, curbs on gold imports and currency trading and liberalization of inflow controls. However, the Rupee depreciation continued unabated (Figure 11). The taper tantrum was officially over when the Federal Reserve did not reduce its monthly purchases under QE in its September 18 monetary policy announcement.

The upshot of this analysis is that a general trend of international capital market liberalization has occurred in India, particularly on the liberalization of capital inflows. Moreover, the intensity of liberalizations coincided with bouts of exchange rate pressure, such as the taper tantrum episode, with changes in capital controls attempting to moderate exchange rate movements. However, it is not clear from the empirical evidence that capital control changes had much impact on exchange rate movements.

\subsection{Monetary Policy, the Trilemma and Exchange rate management}

Monetary policy in India, especially policy interest rates, has occasionally been influenced by external developments as well as directed toward moderating exchange rate movements (Hutchison, Sengupta, and Singh, 2012, 2013). The tradeoffs between an independent interest rate (monetary) policy, exchange rate stability and financial openness (deregulation of capital controls) - the well-known trilemma constraint- is clearly evident in India. The trilemma configuration is an important part of an analysis of factors determining exchange rates in India as exchange rate stability is comprised (given a particular external environment) when authorities pursue greater capital market openness (financial liberalization) or follow an interest rate policy that diverges from the rest-of-the-world (monetary independence).

Policy constraints between these three policy instruments were operating in India over the past decade, as shown in Figure 12. The figure shows the evolution of interest rate policy independence (monetary autonomy, MPA), international capital account openness (KO) and exchange rate stability (ES). The monetary policy autonomy index (MPA) of Aizenman, Chinn and Ito index (2008) is plotted. This index measures the inverse of the correlation between nominal money market interest rates in India and the US, and varies between 0 and 1, with higher values indicating greater monetary policy autonomy. The exchange rate stability index is measured as the normalized annual standard deviation of the monthly percentage changes in nominal INR/USD spot exchange rate and is also from the Aizenman, Chinn and Ito (2008). To measure capital account openness (KO), we use the Lane and Milesi-Ferreti (2007) dataset on external wealth of nations and compute the index as the sum of total financial assets and liabilities as percentage of GDP. 
The MPA index suggests very low monetary policy autonomy during 1999-2007, taking values below 0.5 for the entire period. This period is also characterized by heavy foreign exchange market purchases of USD (leading to large reserves accumulation) and NKI reducing measures, particularly during bouts of intensive exchange rate appreciation pressure (2004 and 2006-07). This is against a background of a gradual trend increase in capital account openness. This period is also characterized, at least until 2004, by relatively high exchange rate stability (ES). ${ }^{11}$ Hence, the trade-off for relative exchange rate stability for most of this period, and increased greater financial openness, is limited monetary autonomy.

Post-2008, higher nominal exchange rate volatility, seen in Figure 2 and measured by lower values of the exchange rate stability index of Figure 12, allowed the authorities to regain some degree of monetary policy autonomy. The MPA index rose back to its pre-1999 values of about 0.5 in 2008, and remained fairly steady till 2012. The exchange rate stability index continued to fall continuously from the mid- to late-2000s and, by 2012, reached a level below that observed in late 1990’s.

The contrast between the late-1990's and post-2008 period suggests that the trade-off between exchange rate stability and monetary policy autonomy worsened in the late-2008 period, i.e. pursuing exchange rate stability was more costly in terms of monetary policy autonomy. ${ }^{12}$ This weakened trade-off between exchange rate stability and monetary policy autonomy was likely driven by the significantly higher financial openness of the Indian economy in post-2008 period as well as larger magnitude and increased variance of external shocks, especially those associated with the Global Financial Crisis (GFC).

Turbulence in the post-GFC continued into 2015, with high exchange rate volatility combined with net capital inflow (NKI) increasing measures and monetary tightening cycles. In particular, both in 2010-11 and 2013-14, monetary policy tightening cycles combined with NKI increasing measures were designed to stem rapid net capital outflows due to loss of investor confidence

\footnotetext{
${ }^{11}$ While it may be difficult to reconcile the higher monetary policy autonomy index with higher inflation in India post-2008, especially compared to much lower MPA index in 2002-07, it is noteworthy that higher MPA levels only indicate that domestic interest rates do not react very frequently to foreign policy changes. They do not allow insight into the particular domestic policy objective. Hutchison et al. (2013) found that prior to 2008, monetary policymakers seemed to put more weight on output gap than inflation in their policy decisions. The post-2008 inflation outcomes may reflect both that monetary policy makers did not put a high weight on inflation in that period (focusing instead on output or other objectives, for example domestic credit growth), and also that they were navigating a more challenging external and domestic conditions, including high commodity prices, stalling of the reform agenda and other structural factors putting pressure on food inflation, as well as more challenging domestic financial conditions due to rising non-performing loans in the domestic banking sector.

12 This result is consistent with evidence in Patnaik and Felman (2013) who find that the exchange rate response for each billion dollar of intervention in India's currency market declined steadily over the 2000 's. ${ }^{12}$
} 
Conflicts between monetary and capital control policies, at least as they affect the value of the Rupee exchange rate, appear several times in India. Table 3 shows the capital control regime change dates, identified by Hutchison, Pasricha, Singh (2012) and updated beyond 2011, together with our judgement of the monetary policy cycle turning points (based on information on the RBI's key policy rates). The capital control regimes are characterized as NKI reducing measures regime (i.e. when most measures taken during the time period were either inflow easing or outflow tightening measures, both of which would tend to increase net capital inflows) or NKI reducing measures regime (where most measures taken were either inflow tightening or outflow easing measures). Monetary policy regimes are described as easing or tightening cycles. We divide the full sample period into 6 regimes.

For the three regimes before November 2009, as well as between October 2011- May 2013, capital control changes seem to be following or supporting monetary policy direction. Easing of monetary policy, which may discourage net capital inflows by making returns less attractive, is associated with NKI increasing measures and tightening of monetary policy is associated with NKI reducing measures, both to counteract overheating of the economy. For these periods, capital controls, at least on the face of it, seem to be supporting monetary policy's focus on the domestic economic cycle. In contrast, in the period November 2009 - October 2011, capital controls and monetary policy are not in tandem, with monetary tightening being conducted at the same time as NKI increasing measures (which may counteract the effect of monetary tightening).

In the May 2013-May 2014 period, monetary tightening and NKI increasing measures again coincide, a period when monetary policy was clearly reacting to outflows of capital. The RBI acknowledged as much in its 2014 annual report in stating that monetary policy between July and September 2013, characterized as a "post-taper tantrum," was geared towards stemming capital outflows by increasing interest rates. For India, this period coincided was one of slowing growth, high inflation and sharp decline in exchange rate. These episodes contrast sharply with the 2004 cycle of monetary tightening which occurred as controls on outflows were reduced marked (while controls on inflows were little changed). Both monetary and capital control policies in 2004 were therefore leaning against the wind, limiting exchange rate changes and slowing an overheated economy.

\section{Conclusion}

Explaining short-run exchange rate movements statistically by a stable set of macroeconomic variables is an elusive task, which is not settled in the literature. Given the state of the academic and policy literature on exchange rate determination, our objectives in this chapter are limited to two main parts: (a) a survey of nominal and real exchange rates in India since the early 1990s, both in terms of trend movements and volatility; and (2) an exploration of the roles of the main 
policy determinants--foreign exchange market intervention, opening of the capital account, and monetary policy-- in influencing the path and volatility of the Rupee exchange rate.

In considering longer-term exchange rate trends in India, we find a strong linkage between a broad based nominal currency index and relative price movements between India and its trading partners (36-country weighted index). Co-integration between the exchange rate and relative prices cannot be rejected, implying that the exchange rate adjusts to reflect relative inflation differentials over longer periods of time, maintaining competiveness levels between India and abroad. Relatively high inflation rates in India are the main factor underlying long-term trend nominal depreciation of the Rupee. The external value of the currency is clearly influenced by domestic price and monetary policy developments over longer-periods of time. No trilemma "trade-off" between monetary policy autonomy and the value of the exchange rate is evident over a sustained period.

The divergences between nominal and real exchange rate developments in India are stark. In real terms, the Rupee has not generally been a "weak" currency since the 1990s, with a relative stable trend value against a broad basket of currencies and experiencing substantial appreciation against the USD and a narrow currency basket. Beyond long-term trends, the Rupee exchange rate has evolved through several distinct episodes during our sample. Most importantly, exchange rate volatility has increased markedly since the mid-2000s, especially since the Global Financial Crisis and its aftermath (Standard deviation of month-to-month percentage changes more than doubled).

Higher exchange rate volatility India is influenced by greater volatility in the external environment and recognition among policymakers that exchange rate flexibility may be a necessary short-term tradeoff to facilitate both a more open capital account and greater monetary policy independence. The IMF has also lauded the benefits of greater exchange rate flexibility as a "shock absorber" to economic disturbances in consultations with the Indian government.

Nonetheless, the India government has attempted to moderate exchange rate appreciation of the Rupee by foreign exchange purchases, increasing the stock of international reserves. This may have had some limited effect on reducing upward pressure on the Rupee during periods of large financial capital inflows. By contrast, little attempt to use intervention operations to limit currency depreciation is evident. Tightening of restrictions on net capital inflows has also been a policy instrument attempting to limit currency appreciation.

In principle, greater exchange rate variability provided the RBI with greater autonomy to set domestic interest rates apart from world interest rate levels, especially in the face of the policy of long-standing policy of gradual international capital market liberalization. Consistent with this prediction, we find that monetary autonomy has increased significantly in line with greater exchange rate volatility. However, greater monetary autonomy has not delivered lower inflation rates in India. This may be because the RBI continues to be concerned with the value of the 
exchange rate even with higher financial openness, but most likely because of greater concern with output and employment in the country. Our monetary policy autonomy index (MPA) only measures the linkage between domestic interest rates and foreign interest rates. MPA does not provide information about the particular domestic objective of monetary policy. The RBI did not respond strongly to inflation in the GFC and post-GFC period. Our analysis indicates that higher inflation in India will translate into longer-term trend nominal depreciation in the Rupee even with substantial short-run deviations around this trend. 


\section{$\underline{\text { References }}$}

Joshua Aizenman, Menzie Chinn and Hiro Ito (2008). Assessing the Emerging Global Financial Architecture: Measuring the Trilemma's Configurations Over Time, National Bureau of Economic Research Working Paper 14533.

Jeffery Amato, Andrew Filardo, Gabriele Galati, Goetz von Peter and Feng Zhu (2005).

Research on Exchange Rates and Monetary Policy: An Overview, BIS Working Papers No. 178.

Michael Hutchison, Gurnain Pasricha and Nirvikar Singh (2012). Effectiveness of Capital Controls in India: Evidence from Offshore NDF Market, IMF Economic Review (2012) 60 (3), 395-438.

Michael Hutchison, Rajeswari Sengupta and Nirvikar Singh (2012). India's Trilemma: Financial Liberalization, Exchange Rates and Monetary Policy, The World Economy 35(1), pp. 3-18, January.

Michael Hutchison, Rajeswari Sengupta and Nirvikar Singh (2013). Dove or Hawk: Characterizing Monetary Policy Regime Switches in India, Emerging Markets Review 16, 183202.

Michael Hutchison, Gurnain Pasricha and Nirvikar Singh (2012). Indian Capital Control Liberalization: Estimates from NDF Markets, IMF Economic Review 60(3), pp. 395-438

Philip R. Lane and Gian Maria Milesi-Ferretti (2007). The external wealth of nations mark II: Revised and extended estimates of foreign assets and liabilities, 1970-2004, Journal of International Economics 73, November, 223-250

India IMF Article IV Consultation (2015).

http://www.imf.org/external/pubs/ft/scr/2015/cr1561.pdf

India IMF Article IV Consultation (2013).

http://www.imf.org/external/pubs/ft/scr/2013/cr1337.pdf

Pandey, R., Pasricha, G.K., Patnaik, I. and A. Shah (2015) Motivations for Capital Controls and Their Effectiveness, Working Paper 2015-5

Pasricha, G.K., Falagiarda, M., Bijsterbosch, M. and J. Aizenman, Domestic and Multilateral Effects of Capital Controls in Emerging Markets, (with Matteo Falagiarda, Martin Bijsterbosch and Joshua Aizenman), NBER Working Paper No. 20822, January 2015.

Patnaik and Felman (2013). Did QE unleash a monetary tsunami? An exchange market pressure approach. 2013 
Reserve Bank of India (2013), Intervention in the Foreign Exchange Markets: the approach of the reserve bank of India”, remarks prepared for Emerging Markets Deputy Governors“ Meeting, hosted by the BIS. Available at: http://www.bis.org/publ/bppdf/bispap73l.pdf 


\section{Chart 1: Nominal exchange rate movements}

Index: January $1998=100$

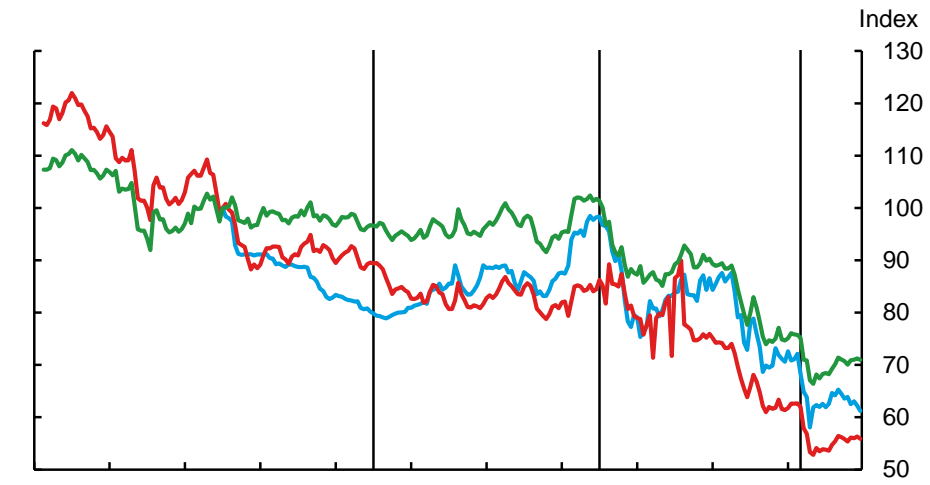

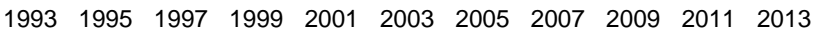

Indian Rupee vis-à-vis US\$

Nominal effective exchange rate - 6 currency index

Nominal effective exchange rate - 36 currency index

Sources: Bloomberg, Reserve Bank of India and Bank of Canada calculations

Last observation: December 2014

\section{Chart 2: Monthly percentage change in nominal exchange rates}

Month-over-month percentage change

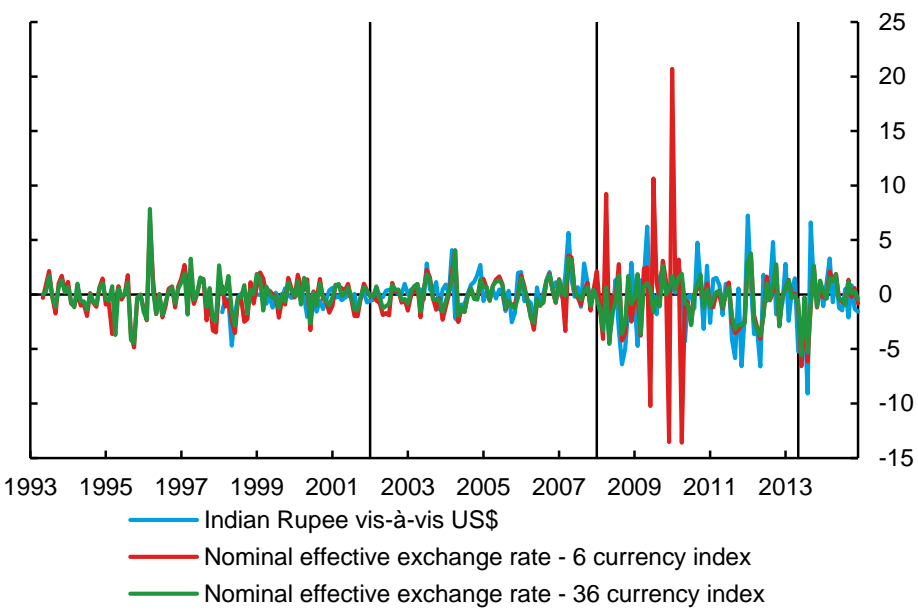

Sources: Bloomberg, Reserve Bank of India and Bank of Canada calculations

Last observation: December 2014 


\section{Chart 3: Real exchange rate movements}

Index: January $2001=100$

Index

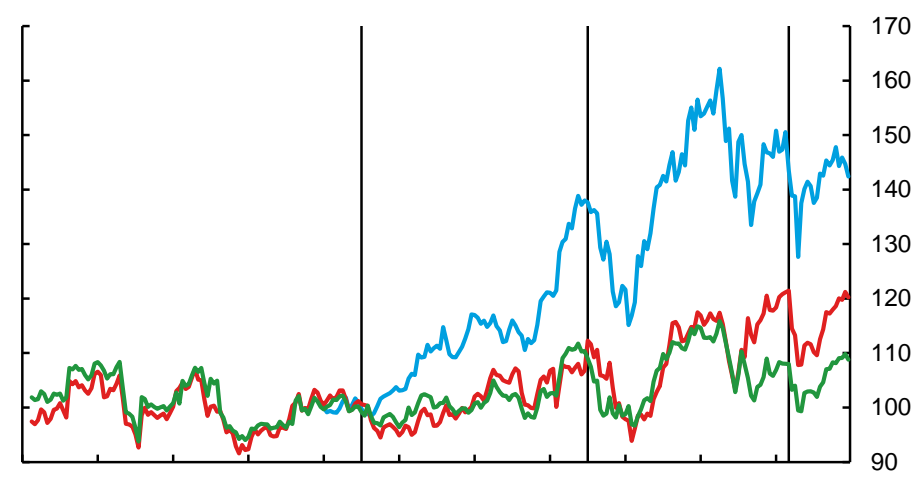

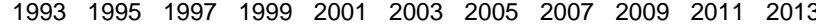

Real Indian Rupee vis-à-vis US\$

Real effective exchange rate - 6 currency index

Real effective exchange rate - 36 currency index

Sources: Bloomberg, Reserve Bank of India and Bank of Canada calculations

Last observation: December 2014

Chart 4: Monthly percentage change in real exchange rates

Month-over-month percentage change

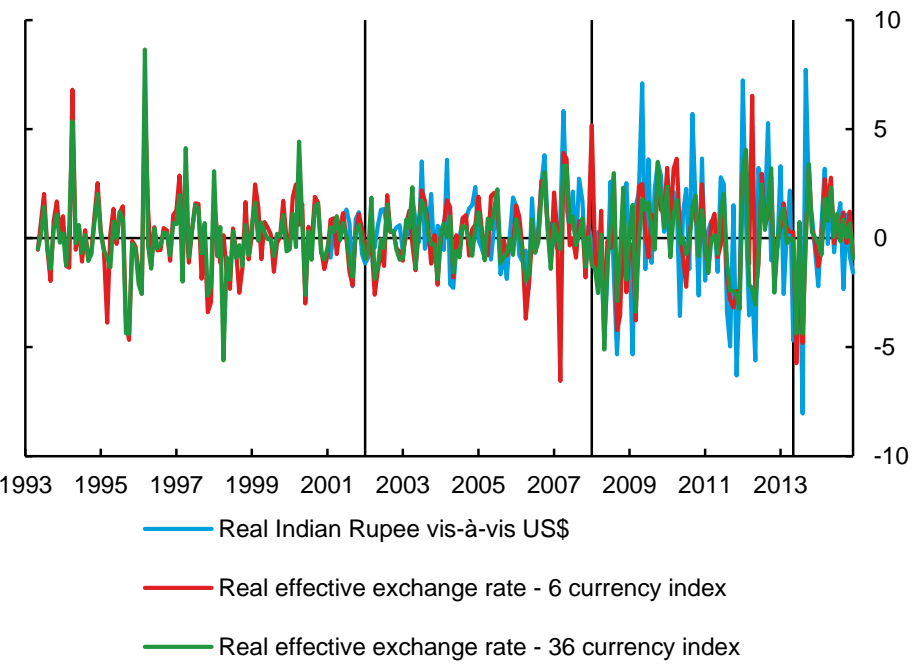

Sources: Bloomberg, Reserve Bank of India and Bank of Canada calculations

Last observation: December 2014 


\section{Chart 5: Relative price movements}

Index: January $2001=100$

$$
\text { Index }
$$

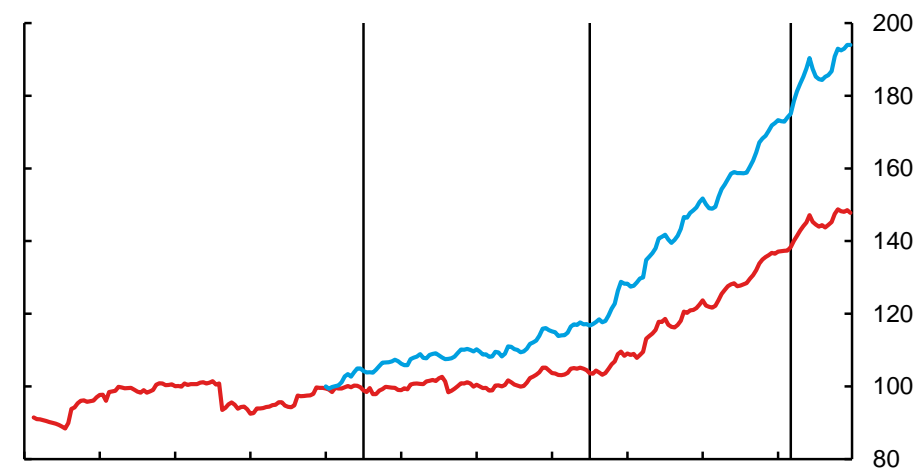

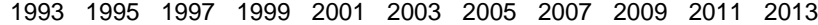

— Real price differential between India and trade-weighted 36 index

Real price differential between India and US\$

Sources: U.S. Bureau of Labor Statistics, India Ministry of Statistics and Programme

Implementation, Reserve Bank of India and Bank of Canada calculations

Last observation: December 2014

\section{Chart 6: Relative price volatility}

Month-over-month percentage change

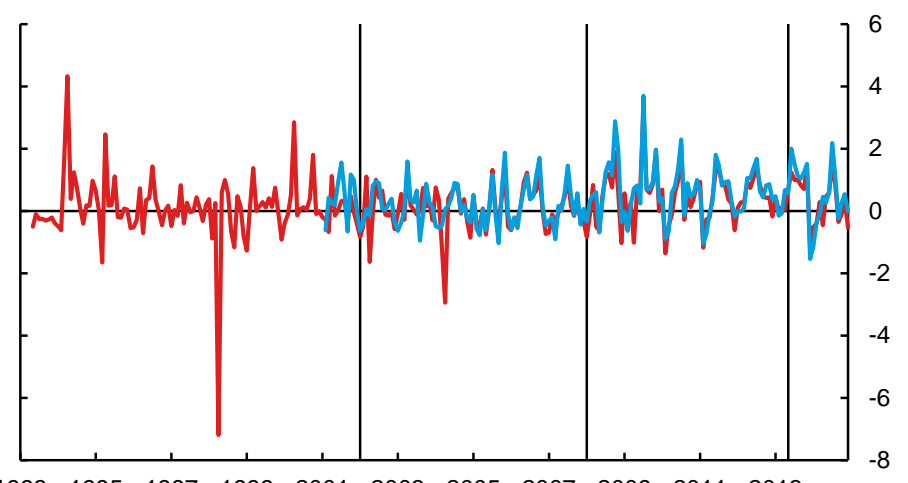

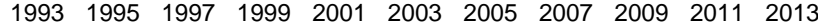

Real price differential between India and trade-weighted 36 index

- Real price differential between India and US\$

Sources: U.S. Bureau of Labor Statistics, India Ministry of Statistics and Programme

Implementation, Reserve Bank of India and Bank of Canada calculations

Last observation: December 2014 


\section{Chart 7: Foreign exchange reserve accumulation}

Monthly data

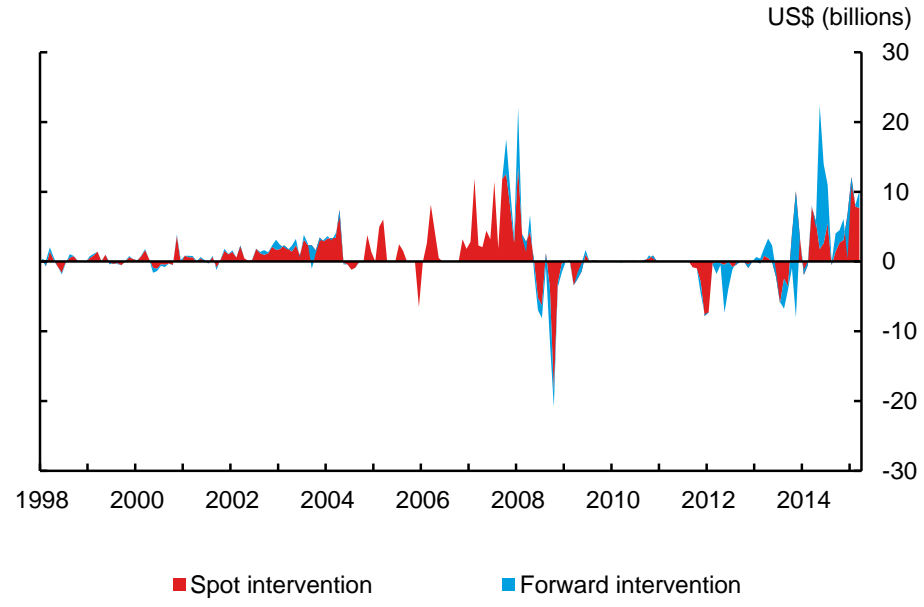

Source: Reserve Bank of India

Last observation: March 2015

\section{Chart 8: Capital control liberalization in India}

Number of policy actions, weighted

Policy actions

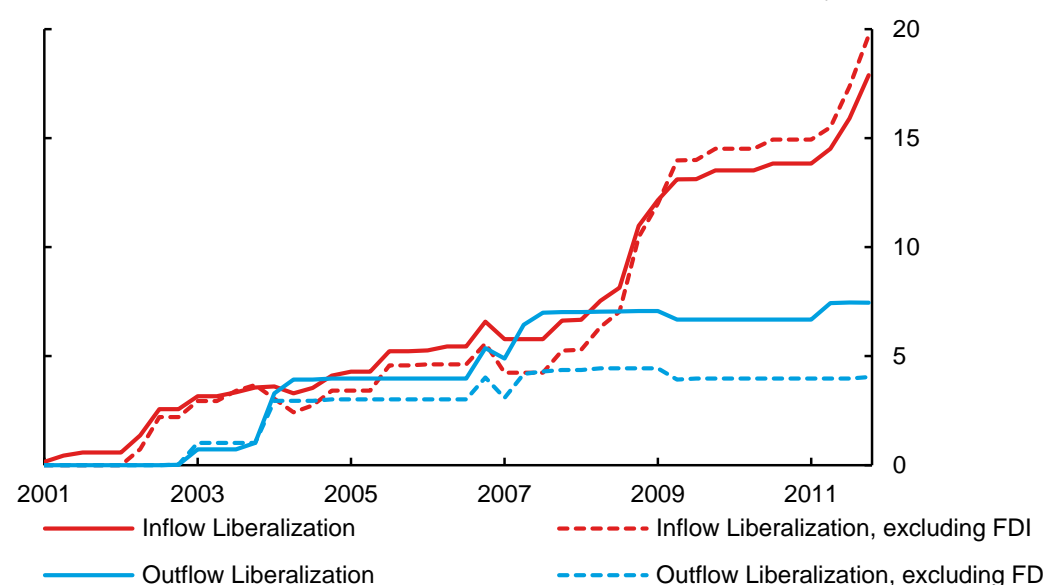

Notes: Each of the capital account openness indices is the cumulative sum of number of weighted capital control easings

less tightenings per quarter. The changes are weighted by the share of the country's international balance sheet the measures

are designed to impact. The weights are from Lane and Milesi-Ferretti, as in Pasricha et al, 2015.

Source: Pasricha, Falagiarda, Bijsterbosch, Aizenman (2015)

Last observation: 2011Q4 


\section{Chart 9a: Capital controls responded to exchange rate pressures}

Easing events

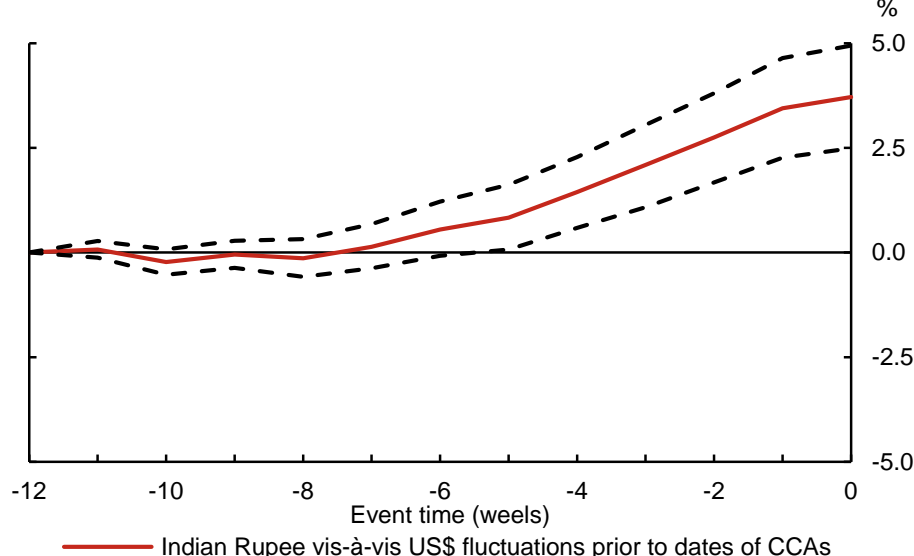

- - - 95th percentile confidence interval

Note: Sample includes 68 easing events.

Source: Pandey et al (2015)

Chart 9b: Capital controls responded to exchange rate pressures

Tightening events

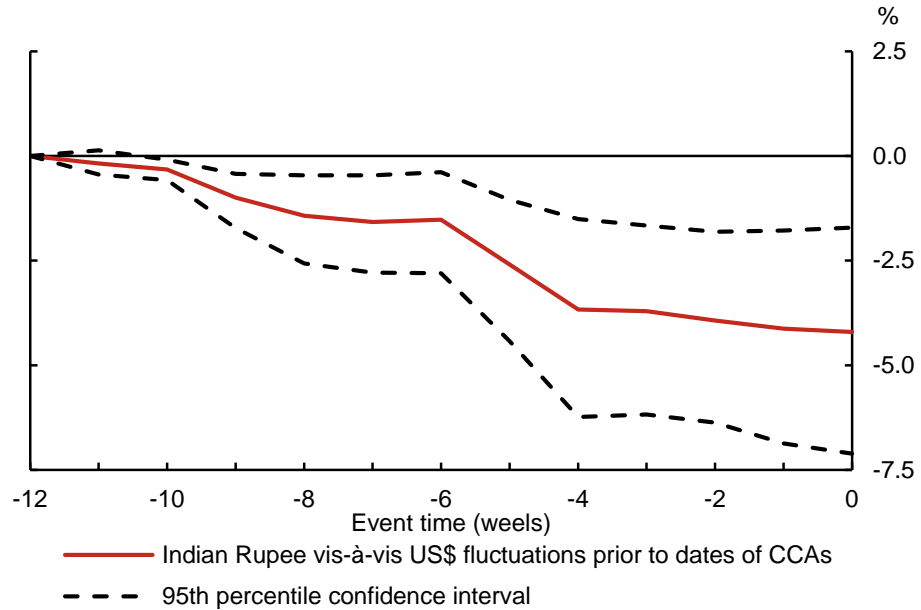

Note: Sample includes 8 tightening events.

Source: Pandey et al (2015) 


\section{Chart 10: Causal impact of capital controls on nominal INR-USD exchange rate}

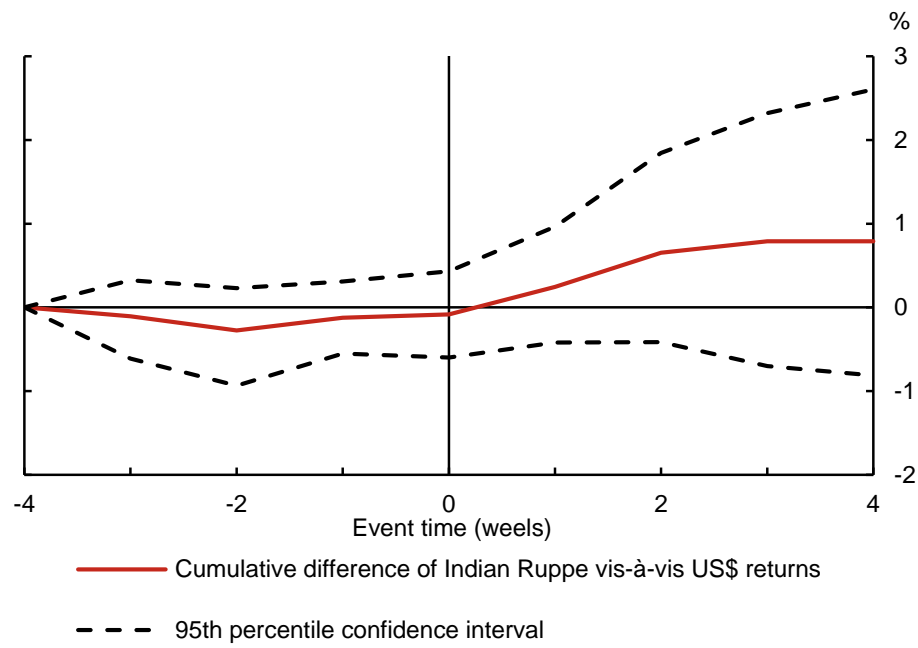

Source: Pandey et al (2015)

\section{Chart 11: Capital controls and INR-USD exchange rate during "taper tantrum"}

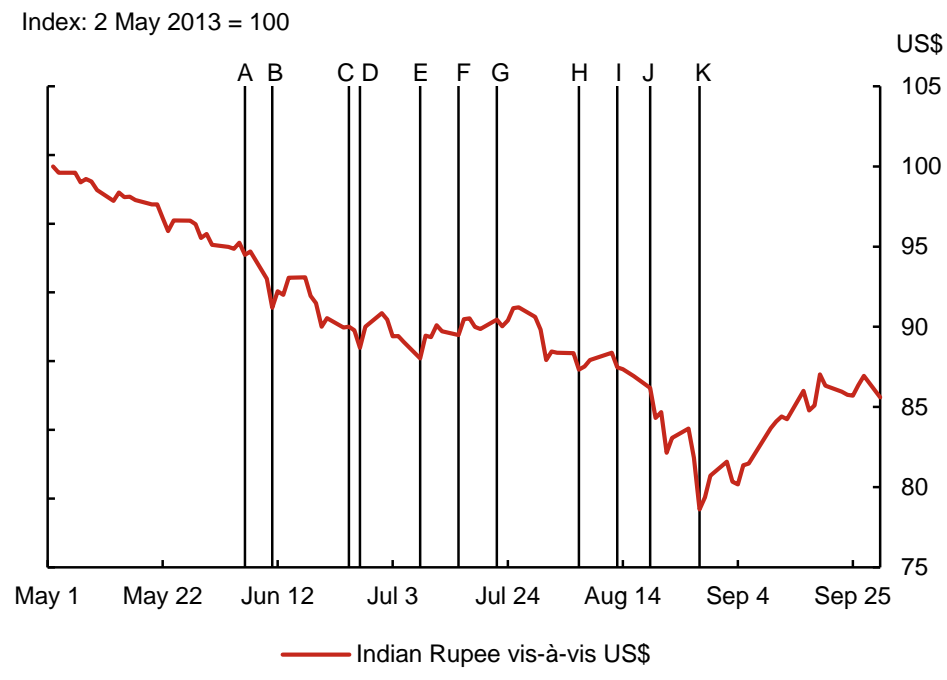

\footnotetext{
a. 22-05-2013 - Bernanke Congressional Testimony

b. 06-06-2013 - Restrictions placed on gold imports

c. 11-06-2013 - Curbs on exporter freedom

d. 25-06-2013 - Restrictions placed on gold imports and easing of restrictions on ECB

e. 08-07-2013 - Proprietary trading ban in currency markets on

f. 15-07-2013 - Interest rate defence and easing of restrictions on ECB

g. 22-07-2013 - Restrictions placed on gold imports

h. 06-08-2013 - Raghuram Rajan appointed Governor of the RBI

i. 13-08-2013 - Restrictions placed on gold imports

j. 18-08-2013 - Easing of restrictions on ECB

k. 28-08-2013 - RBI introduces forex swap window for public sector oil marketing companies
}

Source: Reserve Bank of India and Bank of Canada calculations

Last observation: 30 September 2013 


\section{Chart 12: Trilemma indices for India}

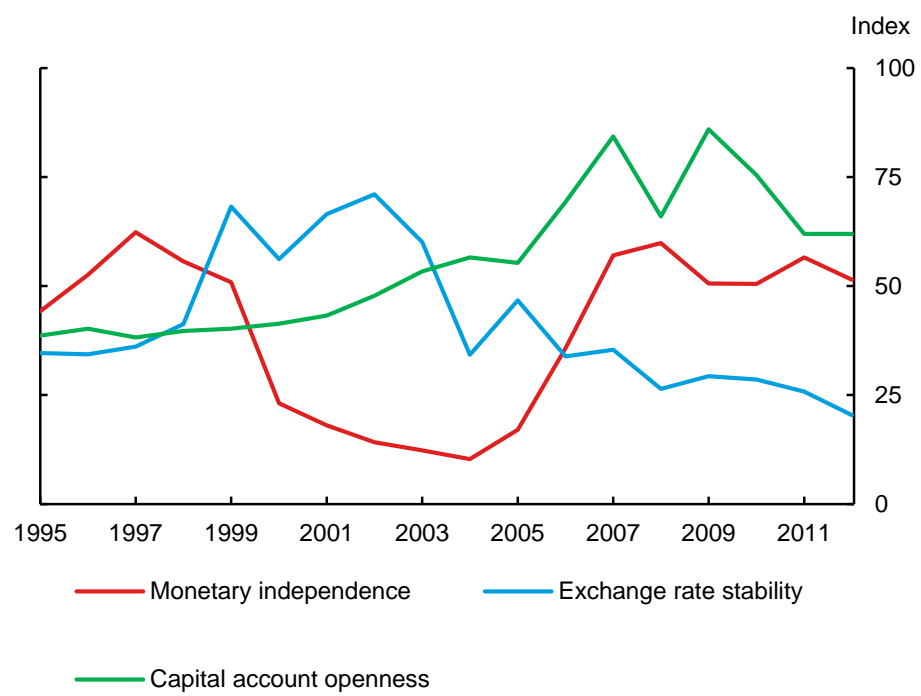

Source: Source goes here

Last observation: 2012 
Table 1: Co-integration between Nominal INR/USD Exchange Rate and Relative CPI

\begin{tabular}{|c|c|c|c|c|}
\hline Variable & Coefficient & $\begin{array}{l}\text { Standard } \\
\text { Error }\end{array}$ & t-Statistic & Probability \\
\hline constant & 0.073 & 0.021 & 3.523 & 0.001 \\
\hline log(RPRICE_IND_US) & -0.416 & 0.063 & -6.582 & 0.000 \\
\hline $\mathrm{R}^{2}$ & 54.9 & & & \\
\hline Adjusted $\mathrm{R}^{2}$ & 54.6 & & & \\
\hline \multicolumn{5}{|c|}{ Null hypoethsis: series are not cointegrated } \\
\hline & Value & Probability* & & \\
\hline Engle-Granger tau-statistic & 0.549 & 0.694 & & \\
\hline Engle-Granger z-statistic & 0.546 & 0.660 & & \\
\hline Phillips-Ouliaris tau-statistic & 0.078 & 0.670 & & \\
\hline Phillips-Ouliaris z-statistic & 0.028 & 0.634 & & \\
\hline
\end{tabular}

Table 2: Co-integration between Nominal Rupee Trade-Weighted (36 countries) Exchange Rate and Relative Prices

\begin{tabular}{|c|c|c|c|c|}
\hline Variable & Coefficient & $\begin{array}{c}\text { Standard } \\
\text { Error }\end{array}$ & t-Statistic & Probability \\
\hline constant & 4.621 & 0.006 & 822.186 & 0.000 \\
\hline $\log (\mathrm{RPRICE} 36)$ & -0.828 & 0.038 & -21.818 & 0.000 \\
\hline $\mathrm{R}^{2}$ & 88.5 & & & \\
\hline Adjusted $\mathrm{R}^{2}$ & 88.5 & & & \\
\hline \multicolumn{5}{|c|}{ Null hypoethsis: series are not cointegrated } \\
\hline & Value & Probability* & & \\
\hline Engle-Granger tau-statistic & -3.371 & 0.058 & & \\
\hline Engle-Granger z-statistic & -21.911 & 0.043 & & \\
\hline Phillips-Ouliaris tau-statistic & -3.528 & 0.039 & & \\
\hline Phillips-Ouliaris z-statistic & -23.991 & 0.027 & & \\
\hline
\end{tabular}




\begin{tabular}{|c|c|c|c|c|}
\hline \multirow{2}{*}{ Begin } & \multirow{2}{*}{ End } & \multirow{2}{*}{ Regime } & \multicolumn{2}{|c|}{ Description } \\
\hline & & & Capital Controls & Monetary Policy \\
\hline September 4, 1998 & July 7, 2003 & $\begin{array}{l}\text { MP: Easing } \\
\text { CC: Some NKI } \\
\text { increasing measures }\end{array}$ & $\begin{array}{l}\text { Slow and tentative } \\
\text { liberalization of } \\
\text { inflows but few } \\
\text { changes }\end{array}$ & $\begin{array}{l}\text { Easing, on all } 4 \\
\text { policy rates. }\end{array}$ \\
\hline July 8, 2003 & October 10, 2008 & $\begin{array}{l}\text { MP: Neutral / Tight } \\
\text { CC: NKI reducing } \\
\text { measures }\end{array}$ & $\begin{array}{l}\text { Outflow } \\
\text { liberalizations and } \\
\text { net tightening of } \\
\text { restrictions on } \\
\text { inflows, particularly } \\
\text { between } 2006 \text { and } \\
2008 \text {. }\end{array}$ & $\begin{array}{l}\text { Tightening, starting } \\
\text { in August } 2004 \text { with } \\
\text { CRR and } \\
\text { October2005 in repo } \\
\text { rate }\end{array}$ \\
\hline October 11, 2008 & November 20, 2009 & $\begin{array}{l}\text { MP: Easing } \\
\text { CC: NKI increasing } \\
\text { measures }\end{array}$ & $\begin{array}{l}\text { Inflow liberalizations, } \\
\text { no change in outflow } \\
\text { controls }\end{array}$ & Easing \\
\hline November 21, 2009 & October 25, 2011 & $\begin{array}{l}\text { MP: Tightening } \\
\text { CC: NKI increasing } \\
\text { measures }\end{array}$ & $\begin{array}{l}\text { Inflow liberalizations, } \\
\text { no change in outflow } \\
\text { controls }\end{array}$ & Tightening \\
\hline October 26, 2011 & May 9, 2013 & $\begin{array}{l}\text { MP: Easting } \\
\text { CC: NKI increasing } \\
\text { measures }\end{array}$ & $\begin{array}{l}\text { Inflow liberalizations, } \\
\text { some outflow } \\
\text { tightenings }\end{array}$ & Easing \\
\hline May 10, 2013 & May 2, 2014 & $\begin{array}{l}\text { MP: Tightening } \\
\text { CC: NKI increasing } \\
\text { measures }\end{array}$ & $\begin{array}{l}\text { Inflow easings, } \\
\text { outflow tightenings }\end{array}$ & Tightening \\
\hline
\end{tabular}


Appendix: Data Sources

\begin{tabular}{|c|c|c|}
\hline Series & Source & Notes \\
\hline Indian Rupee vis-à-vis US\$ & Bloomberg & Spot exchange rate \\
\hline $\begin{array}{l}\text { Nominal effective } \\
\text { exchange rate - } 6 \text { currency } \\
\text { index (NEER6) }\end{array}$ & $\begin{array}{l}\text { Reserve Bank of } \\
\text { India }\end{array}$ & $\begin{array}{l}\text { Index: } 2004-05 \text { (April-March) }=100 ; \text { Trade-based } \\
\text { weights. Current series begins. Data prior to July } \\
2005 \text { spliced from the discontinued NEER series } \\
\text { with earlier base year. }\end{array}$ \\
\hline $\begin{array}{l}\text { Nominal effective } \\
\text { exchange rate - } 36 \\
\text { currency index (NEER36) }\end{array}$ & $\begin{array}{l}\text { Reserve Bank of } \\
\text { India }\end{array}$ & $\begin{array}{l}\text { Index: } 2004-05 \text { (April-March) =100; Trade-based } \\
\text { weights. Current series begins. Data prior to July } \\
2005 \text { spliced from the discontinued NEER series } \\
\text { with earlier base year. }\end{array}$ \\
\hline $\begin{array}{l}\text { Real Indian Rupee vis-à-vis } \\
\text { US\$ }\end{array}$ & Bloomberg & $\begin{array}{l}\text { Index: January } 2001=100 \text {; spot exchange rate } \\
\text { normalized by authors to an index. }\end{array}$ \\
\hline $\begin{array}{l}\text { Real effective exchange } \\
\text { rate }-6 \text { currency index } \\
\text { (REER6) }\end{array}$ & $\begin{array}{l}\text { Reserve Bank of } \\
\text { India }\end{array}$ & $\begin{array}{l}\text { Index: } 2004-05 \text { (April-March) }=100 ; \text { Trade-based } \\
\text { weights. Current series begins. Data prior to April } \\
2004 \text { spliced from the discontinued NEER series } \\
\text { with earlier base year. }\end{array}$ \\
\hline $\begin{array}{l}\text { Real effective exchange } \\
\text { rate - } 36 \text { currency index } \\
\text { (REER36) }\end{array}$ & $\begin{array}{l}\text { Reserve Bank of } \\
\text { India }\end{array}$ & $\begin{array}{l}\text { Index: } 2004-05 \text { (April-March) }=100 ; \text { Trade-based } \\
\text { weights. Current series begins. Data prior to April } \\
2004 \text { spliced from the discontinued NEER series } \\
\text { with earlier base year. }\end{array}$ \\
\hline $\begin{array}{l}\text { Real price differential } \\
\text { between India and trade- } \\
\text { weighted } 36 \text { index (RP36) }\end{array}$ & $\begin{array}{l}\text { Construction by } \\
\text { authors }\end{array}$ & $\begin{array}{l}\text { Index: January } 2001=100 . \text { RP36 = NEER36 / } \\
\text { REER36. }\end{array}$ \\
\hline $\begin{array}{l}\text { Real price differential } \\
\text { between India and US\$ }\end{array}$ & $\begin{array}{l}\text { Construction by } \\
\text { authors }\end{array}$ & India CPI / US CPI. \\
\hline Spot intervention & $\begin{array}{l}\text { Reserve Bank of } \\
\text { India }\end{array}$ & \\
\hline Forward intervention & $\begin{array}{l}\text { Reserve Bank of } \\
\text { India }\end{array}$ & $\begin{array}{l}\text { Forward intervention series is a net amount } \\
\text { outstanding. We take month-over-month level } \\
\text { change to show intervention }\end{array}$ \\
\hline $\begin{array}{l}\text { Capital control } \\
\text { liberalization indices } \\
\text { (inflow and outflow } \\
\text { liberalizations, including } \\
\text { and excluding FDI) } \\
\end{array}$ & $\begin{array}{l}\text { Pasricha, } \\
\text { Falagiarda, } \\
\text { Bijsterbosch, } \\
\text { Aizenman (2015) }\end{array}$ & $\begin{array}{l}\text { Weighted number of capital control actions, } \\
\text { cumulated over time. Non-cumulated, weighted } \\
\text { data from source. }\end{array}$ \\
\hline $\begin{array}{l}\text { Monetary independence } \\
\text { Index }\end{array}$ & $\begin{array}{l}\text { Aizenman, Chinn } \\
\text { and Ito (2008) }\end{array}$ & $\begin{array}{l}\text { This measures the correlations between nominal } \\
\text { short term money market interest rates in India } \\
\text { and the USA. Higher numbers indicate lower } \\
\text { correlations, i.e. higher monetary policy } \\
\text { autonomy. }\end{array}$ \\
\hline $\begin{array}{l}\text { Exchange rate stability } \\
\text { Index }\end{array}$ & $\begin{array}{l}\text { Aizenman, Chinn } \\
\text { and Ito (2008) }\end{array}$ & $\begin{array}{l}\text { This measure is the normalized annual standard } \\
\text { deviation of the monthly percentage changes in } \\
\text { nominal INR/USD spot exchange rate }\end{array}$ \\
\hline $\begin{array}{l}\text { Capital account openness } \\
\text { Index }\end{array}$ & $\begin{array}{l}\text { Lane and Milesi- } \\
\text { Ferretti (2007) }\end{array}$ & $\begin{array}{l}\text { Total foreign assets and liabilities, as percentage } \\
\text { of nominal GDP. Both measured in US Dollars. }\end{array}$ \\
\hline
\end{tabular}

